\title{
OPEN Author Correction: Functionally Enigmatic Genes in Cancer: Using TCGA Data to Map the Limitations of Annotations
}

\author{
Alexandra Maertens, Vy P. Tran, Mikhail Maertens, Andre Kleensang (D, \\ Thomas H. Luechtefeld, Thomas Hartung \& Channing J. Paller
}

Correction to: Scientific Reports https://doi.org/10.1038/s41598-020-60456-x, published online 05 March 2020

The original version of this Article contained a typographical error in the spelling of the author Vy P. Tran, which was incorrectly given as Vy H. Tran.

As a result, within the Acknowledgements section:

"V.H.T. is supported by NIH training grant number 2T32ES007141. C.P. is supported by NIH grant numbers P30CA006973 and K23 CA197526."

now reads:

"V.P.T. is supported by NIH training grant number 2T32ES007141. C.P. is supported by NIH grant numbers P30CA006973 and K23 CA197526."

Finally, the Author Contributions section:

“Conceptualization, A.M., C.P.; Methodology, A.M., T.H.L., V.H.T.; Formal Analysis, A.M., V.H.T., T.H.L., M.M., A.K.; Writing—Review \& Editing, A.M., V.H.T., C.P., T.H.; Visualization, V.H.T., A.M.; Supervision: C.P., T.H.”

now reads:

"Conceptualization, A.M., C.P.; Methodology, A.M., T.H.L., V.P.T.; Formal Analysis, A.M., V.P.T., T.H.L., M.M., A.K.; Writing-Review \& Editing, A.M., V.P.T., C.P., T.H.; Visualization, V.P.T., A.M.; Supervision: C.P., T.H.”

This has now been corrected in the PDF and HTML versions of the Article.

(c) (i) Open Access This article is licensed under a Creative Commons Attribution 4.0 International License, which permits use, sharing, adaptation, distribution and reproduction in any medium or format, as long as you give appropriate credit to the original author(s) and the source, provide a link to the Creative Commons license, and indicate if changes were made. The images or other third party material in this article are included in the article's Creative Commons license, unless indicated otherwise in a credit line to the material. If material is not included in the article's Creative Commons license and your intended use is not permitted by statutory regulation or exceeds the permitted use, you will need to obtain permission directly from the copyright holder. To view a copy of this license, visit http://creativecommons.org/licenses/by/4.0/.

(C) The Author(s) 2020 